\title{
Database Temperate Deciduous Forests of the Prignitz Region
}

\author{
Monika Wulf
}

\begin{abstract}
For her own habilitation Monika Wulf investigated 232 plots (vegetation relevés) in 63 mixed broadleaf forests from 1996 to 1999 . The 232 plots $\left(100-400 \mathrm{~m}^{2}\right)$ represent alder-ash dominated stands on wet and moist sites, oak-hornbeam forests on fresh soils, and beech dominated forests on moderately fresh soils. In each plot the abundance of all vascular plants per stratum (first and second tree layer, shrub and herb layer) was estimated using the scale of Barkman. Bryophytes were noted as presence/absence data. The location of each plot was drawn in topographical maps at scale 1:25,000 with an average deviance of 100-200 m. Additionally sketches with positions of the main tree and shrub species within the plot and at the plot boundaries were drawn. It is planned for 2010 or latest 2011 to relocate plots exactly and fixing their positions by means of GPS. In a selected number of 151 plots from 55 forests soil samples were taken at three different horizons $(0-5 \mathrm{~cm}, 5-10 \mathrm{~cm}$, and 10-20 cm). At each plot 10 sub-samples were taken with a soil auger of $5 \mathrm{~cm}$ diameter, and were mixed separately for the three horizons to one sample. The soil samples were used to estimate the $\mathrm{pH}$ using a $\mathrm{CaCl}_{2}$-standard solution, and to determine the amount of the plant available cations $\mathrm{Ca}, \mathrm{K}, \mathrm{Mg}$ and $\mathrm{P}$ using an ammoniumacetate-solution. Determination of the cation concentrations were made with a spectral photometer and an atom-absorptionsspectrometer (AAS), respectively. For at least $80 \%$ of all plots site nutrient and moisture regime as well as humus nutrient and moisture regime were compiled from maps of the forest site inventories of the 1950s and 1960s. This report describes the available content in the vegetation Database Temperate Deciduous Forests of the Prignitz Region (GIVD ID EU-DE-006).
\end{abstract}

Keywords: abundance; forest inventory; humus form; Melico-Fagetum; pH; plant available cation; Pruno-Fraxinetum; StellarioCarpinetum.

\section{Database Temperate Deciduous Forests of the Prignitz Region}

Scope: Analysis of distribution pattern of selected herbaceous plant species in relation to long-termed land-use/cover changes (1780-1980) in the Prignitz region (habilitation of Monika Wulf)

Status: finished

Period: 1996-1999

Database manager(s): Monika Wulf (mwulf@zalf.de)

Owner: Prof. Dr. Monika Wulf, Leibniz-ZALF, Institute of Land Use Systems

Web address: http://www.zalf.de/home_zalf/institute/lse/lse/mitarbeiter/wulf/general.htm

Availability: according to a specific agreement

Online upload: no

Database format(s): Excel

Export format(s): [NA]

Publication: [NA]

Plot type(s): normal plots

Non-overlapping plots: 232

Plot-size range: $100-400 \mathrm{~m}^{2}$

Total plot observations: 232

Estimate of existing plots: 232

Completeness: $100 \%$

Countries: DE: $100.0 \%$

Forest: [NA] — Non-forest: [NA]

Guilds: all vascular plants: $100 \%$; bryophytes (terricolous or aquatic): $100 \%$

Environmental data: surface cover other than plants (open soil, litter, bare rock etc.): $80 \%$; soil pH: $65 \%$

Performance measure(s): cover: $100 \%$

Geographic localisation: point coordinates less precise than GPS, up to $1 \mathrm{~km}: 100 \%$

Sampling periods: 1990-1999: 100.0\%

Information as of 2012-07-12; further details and future updates available from http://www.givd.info/ID/EU-DE-006

Monika Wulf (mwulf@zalf.de)

Institute of Land Use Systems, Centre for Agricultural Landscape Research (Leibniz-ZALF), Eberswalder Str. 84, 15374 Müncheberg, GERMANY 